\title{
Factors affecting Corporate Cash Holdings: A study of Non- financial Institutions Listed on the Ghana Stock Exchange.
}

\author{
Wilson Elorm Pekyi* Zhang Wenfang \\ School of Finance and Economics, Jiangsu University, No. 301 Xuefu Road, Zhenjiang City, Jiangsu \\ Province, China 212013 \\ *E-mail: pekyi34@gmail.com zhangwf@ujs.edu.cn
}

\begin{abstract}
This article intended to investigate the determinates of cash holding of registered non-financial institutions (NFIs) on the Ghana Stock Exchange (GSE). The research used panel data obtained from the twenty-five enterprises, for the period 2012-2018. The article adopted the robust fixed effect regression technique to empirically find the determinates of cash holdings. The research findings indicated an adverse nexus between cash holdings and capital structure. The profitability of the enterprise shown a positive and significant affiliation with industry cash holdings. Similarly, the size of the firms exhibited statistically a significant connection with enterprise cash holdings. The interest rate and inflation rate both indicated a positive and negative link. The article results are of significant source for enterprises registered on the GSE market to make the proper decision on the volume of cash to hold
\end{abstract} Keywords: Cash holdings, robust fixed effects, leverage, Non-financial institutions, profitability.

DOI: $10.7176 /$ RJFA/11-18-18

Publication date:September $30^{\text {th }} 2020$

\section{Introduction}

Cash is the most liquid and the least profitable asset that plays an important role in corporate finance. Despite the metaphor: "Cash is the lifeblood of every company" is being used almost inflationary by various textbooks and academics within the business domain, it is still a good phrase to highlight the importance of the concept (Hilgen, 2015). Hence, when talking about cash, the first central question that emerges is: "What are the reasons for a company to hold cash?" Corporate cash holding is one of the most essential issues and strategies of corporate financial management, which not only relates to corporate operation and development but also relates to the corporate governance and the institutional environment (Zaheer, 2017). Capital structure is characterized as the means to fund an institution. This is also the amount of short- and long-term debt in business and is weighed when evaluating capital structure. It's the debt and equity balance a company holds. The option of capital structure has been a matter of considerable concern in the study of corporate finance. It is because the combination of investments (leverage ratio) determines the expense and supply of funding and, thus, the basis of investment for firms. However, generating significant sums of cash leads to multiple taxations, especially for international corporations that pay taxes in the host nation and are also subject to tax charges when repatriating financial profits to their home country (Foley et al., 2007), agency costs incurred as a result of disputes between managers (shareholder agents) and shareholders (Harford, Li, and Zhao, 2008), and opportunity costs (Uyar, 2008) and opportunity cost (Uyar and Kuzey, 2014). Holding vast amounts of cash will lead to inefficiency. That is, the company could lose any valuable opportunities for investing. Firms carry cash for motives towards purchases, precautionary motives, motives for organizations, and even for tax motives. The theory of pecking order suggests that companies appear to rely more on internal funding than on external funding when making their investment decisions (Myers, 1984) while on the other hand, the theory of agencies (Jensen, 1986) points out a weakness which is that when managers have surplus cash they do not rely on external sources of finance. Pecking order theory suggests that firms tend to rely on internal financing more than external financing while making their investment decisions (Myers, 1984) and on the other side, agency theory (Jensen, 1986) points out a flaw, that is, when managers have excess cash, then they do not go for external sources of finance. They carry out investment proposals that might also have a lower net present value and end up being negatively impacted by the shareholders. A cash holding strategy is an important financial decision for firms. However, Corporate cash holding pattern varies from one company to another. The rationale behind such decisions differs depending on the firm's capital structure. Most companies hold a high level of cash which has an additional cost. There is a need to study whether this cash holding affects the value of their company or not. According to Gichaiya and Ishmail (2014) cash crisis experienced by firms is worse when the firms have more debt-based capital structure than a more equity-based capital structure. Anon (2018 also argue that highly leveraged firms would face significant costs in debt funding since they are deemed to face a high default risk rate. Therefore, for firms to avoid a cash crisis resulting from 
failure to cover short-term liabilities due to the corresponding huge long-term financial cost burden, the firms must adopt a cash holding level that matches their capital structure. In light of the recent financial and banking crisis in the country which has impacted on the cash levels in the financial space, it is necessary to investigate how the capital structure could be affected concerning cash holding decisions in the GSE's non-financial firms. This information would assist the GSE's non-financial firms to establish the optimal level of cash holding based on their capital structure information. This study, therefore, seeks to articulate the link between capital structure and prudent cash holding in the non-financial firms listed in the Ghana Stock Exchange (GSE). This article employed the robust fixed effect regression analysis to test the nexus of Non-financial firms registered on the Ghana Stock Exchange. There are two main goals to the study. First, we studied the decision of Ghanaian companies on the cash holdings, with special interest in the relationship between capital structure and cash holdings. Next, we examined the cash holdings determinants, with a strong focus in the effect on overall leverage while accounting for other significant variables. Separately, many papers studied the capital structure and cash holdings, but fewer studies reconciled these important topics in a single study, particularly in Ghana. We tackle this problem in our study, hence presenting contributive insights.

\section{Literature and hypothesis development}

The fiscal crisis of (2007-2009) breakdown has sponsored the concentration to cash holdings pointing towards attempts to improve the company's cash management policies. Inspiration toward this area is specifically turn out by the reality that organizations hoard a significant volume of cash that can be easily seen in their financial statements. In the wake of the daunting effects and subsequent failure as experienced by numerous globally reputed corporations arising from cases of financial distress. These companies that include: General Motors in 2009, Swissair in 2001, The CIT Group in 2009, Conseco in 2002, Pacific Gas and Electric Ltd in 2001, Delta Airlines in 2005, Parmalat in 2003, Enron in 2001 and WorldCom in 2002 represented the symbols of corporate financial strength before bankruptcy disclosure. This undesirable phenomenon motivated finance scholars to commence research aimed at examining the underlying causes of the cash crisis in firms. This section reviews past empirical studies that have examined cash holdings and its determinates in decisions in non-financial firms, and macroeconomic factors like interest rate, and inflation rates. This paper mainly studies the impact of micro factors on the corporate cash holdings.

\subsection{Leverage and Corporate Cash Holdings}

Cash levels are recommended to decline, with more debt, because of the increased likelihood of financial loss leveraged companies are more likely to accumulate funds. Accordingly, companies with more liquid reserves will cash these funds and retain lower cash volumes in turn (Al-Najjar and Belghitar, 2011). Enterprises can also use debt to satisfy their funding needs. The expected relationship, in the trade-off principle, is unclear, as the use of equity instead of cash has many drawbacks and benefits. Leverage increases the risk of a company going bankrupt and the expense of financial distress. To avoid these threats, then stand firm higher cash holding levels accrue (Ferreira and Vilela, 2004). Al-Najjar and Belghitar (2011) results show a negative affiliation between leverage and cash holdings. Similarly, Caldeira and Loncan (2013) examined the relationship between capital structure, cash reserves, and firm valuation for a subset of Brazilian publicly traded companies using the fixed-effects estimator by panel data regressions. The findings of this analysis indicated that debt, both short and long-term, is adversely linked to cash reserves, lower leverage is also correlated with the number of cash holdings. In Nigeria, Eneh, Okegbe, and Ndubuisi (2019) investigated the cash holdings of agricultural firms registered for 2008-2017. The OLS regression test indicated that there exists a negative nexus between enterprise cash holdings and leverage. Aftab et al. (2018) researched the determinates of regional cash holdings among the Asia Pacific, Europe, Africa, North America, Middle East, and South America for the period 2007-2016. With a sample of 47 countries, the analysis was conducted through the Panel Generalized Method of Moments. The results of the regression analysis produce a negative and significant affiliation between cash holdings and industry leverage. Nguyen and Le Minh (2017) investigated on 105 registered enterprises on the Ho Chi Minh Stock Exchange for the years 2009 up to 2014. The research results indicated an adverse nexus between leverage and cash holdings. Ferreira and Vilela (2004) suggest that high-debt firms are less in a position to stockpile cash. This is how they are closely tracked as compared to comparatively low-debt firms. From the empirical investigations and the trade-off concept, the first hypothesis is:

\section{H1. There is a negative association between leverage and cash holdings.}




\subsection{Profitability and Corporate Cash Holdings}

Companies need to create liquidity buffers to grow earnings and revenues by ensuring that the pacing of capital flows creates an effective favorable liquidity flow situation (Gill and Shah, 2012). Carrying cash helps businesses to get the best timing for exercising investment and avoiding the underpricing problem. The cord main of any enterprise is to make a profit and maximize shareholder's wealth. Centered on the funding hierarchy, cash is a product of the borrowing and spending practices (Dittmar et al., 2003). Profitable companies are now more likely to pay dividends, pay their debt obligations, and invest in stockpiles. Less profitable firms will be keeping less cash and raising bonds to fund their projects. Such firms would be hesitant to offer shares due to such issuance's high costs (Al-Najjar and Belghitar, 2011). Raheman and Nasr (2007) found a considerable negative affiliation between liquid assets and efficiency over the period 1999-2004, using a survey of 94 Pakistani public firms. In comparison, for four years, Lyroudi and Lazaridis (2000) studied the registered firms on the London Stock Exchange. They observed that the period of cash transfer, the current ratios, and the quick ratios impacted the profitability of companies. Dittmar et al. (2003) suggest in the same way that companies with weak cash balances draw down their capital and raise bonds to fund production, but refrain from offering equity because it's too risky. Therefore, a strong correlation exists regarding the profitability of the company and the cash holdings. This article hypothesizes based on the scientific observations and pecking order theory:

\section{H2. There is a positive association between profitability and cash holdings}

\subsection{Firm size and Corporate Cash Holdings}

Firm size is a significant factor that a company takes into consideration when planning to hold a level of cash. Because of the high prices of external funding, small companies are seen to carry more cash than their major peers. Large corporations are perceived to be more stable than their small peers and in effect less vulnerable to bankruptcy-related losses (Al-Najjar \& Belghitar, 2011) and therefore less likely to store cash reserves. Likewise, it may be argued that big companies have less knowledge asymmetry (as opposed to small firms), and therefore their executives have more leverage in financial strategies and effect would carry more cash for these firms. In a similar vein, Ozkan and Ozkan (2004) suggested that an adverse nexus exits with cash holdings should be expected if the firm size is a proxy for information asymmetry which reflects the external financing costs. However, if company size is used as an indicator of financial distress, then it is more likely that small businesses may be liquidated if they experience financial distress. Thus, these companies keep more cash to escape this condition of pressure (Ozkan \& Ozkan, 2004). Kamal (2017) explores the determinants of cash reserves for 417 publicly listed entities whose shares were quoted on the Indonesian Stock Exchange between 2010 and 2016. The determinants of the cash holdings used in this study come from the concept of trade-off, pecking order, and organization. We prove that there is a significant link between firm size and cash holdings. Aftab et al. (2018) conducted a regionallybased study on 47 countries with an observation of 5757 companies for the year 2007-2016. Through the Panel Generalized Method of Moments concept, firm size had a favorable nexus with the cash holdings of the enterprises. In London, Le et al. (2018) researched the factors that influence corporate cash holdings on registered non-financial enterprises for the period 2011 - 2016. The results of the study investigation indicated a positive and significant affiliation between enterprise size and cash holdings. However, there exists an investigation that has shown a negative outcome. The article, therefore, contends that business size is an important significant determinant of cash holdings and do not forecast the relationship sign between enterprise size and cash holdings:

\section{H3. There is a negative/positive affiliation between firm size and cash holdings}

\section{Methodology}

\subsection{Sample selection and data collection}

Soeters, Shields, and Rietjens (2014) argues that when conducting studies, it is critical to making consideration of various research paradigm and matters of ontology and epistemology since these parameters describe the perceptions, beliefs and assumptions and nature of reality and truth and they, therefore, have a significant influence on how a study is undertaken. This research focuses on using the positivist research philosophy where the terms objectivist, quantitative, and scientific core of the methodological design. Positivism is based upon the values of reason, truth, validity and pure facts gathered through direct observations measured empirically using quantitative methods (Crossman, 2018). This research specifically focuses on the non-financial firms that are listed in the Ghana Stock Exchange Market. There is a total of 42 institutions registered on the GSE market. However, this 
article adopted only 25 enterprises. The remaining are financial firms, suspended firms, enterprises with incomplete accounts for the period of the study. The period of this study is from 2013 - 2018. Descriptive and inferential techniques of data analysis were used for this study. In the descriptive analysis, the mean, standard deviation, minimum and maximum values of both the response and predictor variables were analyzed. On the other hand, the Pearson Product-Moment Correlation Coefficient technique was adopted to examine the relationship that existed between capital structure and the firms' cash holding, whilst the Robust Fixed effect regression technique was employed to determine the effect of capital structure on the enterprise's cash holdings. Before the descriptive and inferential analysis of data, tests for data normality, heteroscedasticity, and multicollinearity were conducted. These tests were to help choose the appropriate regression estimator for the study. All the data analyses were conducted through the use of STATA version 15 software package with a $5 \%$ level of significance $(\mathrm{p} \leq 0.05)$.

\subsection{Variable description}

All variables are summarized and presented in Table 1.

Table 1. description of variables

\begin{tabular}{|l|l|l|l|}
\hline \multicolumn{2}{|c|}{ Variables } & Symbol & Measurement \\
\hline $\begin{array}{l}\text { Dependent } \\
\text { variable }\end{array}$ & Cash holding & Cas__H & $\begin{array}{l}\text { Current assets divided by current } \\
\text { liability }\end{array}$ \\
\hline \multirow{2}{*}{$\begin{array}{l}\text { Independent } \\
\text { variables }\end{array}$} & Leverage & Lev & $\begin{array}{l}\text { Total debt divided by Total } \\
\text { Assets }\end{array}$ \\
\cline { 2 - 4 } & Profitability & Prof & $\begin{array}{l}\text { Operating profit divided by Total } \\
\text { Revenue }\end{array}$ \\
\cline { 2 - 4 } & Firm Size & SZ & Natural Log of Total Assets \\
\hline $\begin{array}{l}\text { Control } \\
\text { variables }\end{array}$ & Inflation Rate & INFL_R & Annual inflation rate \\
\cline { 2 - 4 } & Interest Rate & INT_R & Annual interest rate \\
\hline
\end{tabular}

\subsection{Model specification}

Cash_H $\mathrm{H}_{\mathrm{it}}=\alpha+\beta_{0} \mathrm{X}_{\mathrm{it}}+\mu_{\mathrm{it}} \ldots \ldots \ldots \ldots \ldots \ldots \ldots \ldots$.equ 1

Where Cash_H is the cash holding of the firms, $\alpha$ is the constant, $\beta$ is the beta coefficient of the slope of the variables, $\mathrm{X} \overline{\text { is }}$ the vector of the predictors, and the error team represented by $\mu$.

To deduce the econometric model,

Cash_H ${ }_{i t}$ is the function for cash holdings represented by cash and cash equivalents

Cash_H $\mathrm{H}_{\mathrm{it}}=\mathrm{f}(\mathrm{Lev})$ equ 2

Similarly, $\mathrm{X}_{\mathrm{it}}$ is the function of cash holding,

$\mathrm{X}_{\mathrm{it}}=\mathrm{f}$ (cash holding) but cash holding is measured by (Lev, Prof, SZ, INFL_R, and INT_R)

$\mathrm{Xit}=(\mathrm{Lev}$, Prof, SZ, INFL_R, and INT_R $)$ equ 3.

Forming an econometric model from equ 2 and 3 into equ 1

Cash_H ${ }_{i t}=\alpha_{+} \beta 1$ Lev $+\beta 2$ Prof $+\beta 3 \mathrm{SZ}+\beta 4 \mathrm{INFL} \_\mathrm{R}+\beta 5 \mathrm{INT} \_\mathrm{R}+\mu$ it .equ 4.

\section{Result and discussions}

This section presents the results and discussions of the study. The section is divided into parts. The first present results on the tests for data normality, heteroscedasticity, and multicollinearity test. The second part tackles the model specification and estimation, whilst the third part presents a descriptive analysis of the study's variables. The final part of this section brings to light the results and discussions on the nexus between cash holding and its determinates. 


\subsection{Test for data validity and reliability}

\subsubsection{Shapiro-Wilk (1965) Test for Data Normality.}

The Shapiro-Wilk (1965) test was adopted to test the normality of the data. In frequentist statistics, it is a measure of normality with the null assumption that a sample X1....Xn originated from a normally dispersed population (Shapiro \& Wilk, 1965). So, the Shapiro Wilk test's null hypothesis is that usually the population is distributed (Razali \& Wah, 2011). In other words, if the p-value is smaller than the alpha point chosen, then the null hypothesis is dismissed and there is proof that the data being evaluated does not come from a typically distributed sample. On the other hand, if the p-value is higher than the alpha degree chosen, then it is not feasible to dismiss the null hypothesis that the data examined derived from a normally distributed population (Razali \& Wah, 2011). The chosen alpha level for this study was $5 \%(\alpha=0.05)$. Therefore, the Shapiro-Wilk tested the null hypothesis that all data values of Lev, Cash_H, Prof, SZ, INFL_R, and INT_R were not normally distributed at the 5\% level of significance. As depicted in Table 1, Lev had a W-test coefficient of 0.45440, a V-value of 63.484, a Z-value of 9.410, and a p-value of 0.00000 . The test was statistically significant at the $5 \%$ level of significance $(\mathrm{p}<0.05)$. Thus, the study rejected the null hypothesis that, all the data values of Lev were normally distributed and accepted the alternative hypothesis that, all the data values of Lev were not normally distributed at the $5 \%$ level of significance.

Table 2. Data Normality (Shapiro-Wilk) test

\begin{tabular}{lcllll}
\hline Variable & Obs & $\mathbf{W}$ & $\mathbf{V}$ & $\mathbf{z}$ & Prob>z \\
\hline Lev & 150 & 0.45440 & 63.484 & 9.410 & 0.00000 \\
\hline Cash_H & 150 & 0.34752 & 75.920 & 9.816 & 0.00000 \\
\hline Prof & 150 & 0.67857 & 37.400 & 8.211 & 0.00000 \\
\hline SZ & 150 & 0.95698 & 5.005 & 3.651 & 0.00013 \\
\hline INFL_R & 150 & 0.92695 & 8.500 & 4.852 & 0.00000 \\
\hline INT_R & 150 & 0.96214 & 4.405 & 3.361 & 0.00039
\end{tabular}

Similarly, the W-test, a V-value, and Z-value for all the remaining variables depleted a $\mathrm{p}$ value of 5 percent. This result leads to the rejection of the null hypothesis and accepted the alternative hypothesis that all the variables are not normally distributed at a significant level of $5 \%$.

\subsubsection{TEST FOR HETEROSKEDASTICITY}

According to Muhammad (2012), there is heteroscedasticity that the Ordinary Least Squares (OLS) estimators are no longer the Best Linear Unbiased Estimators (BLUE) because they become inefficient and lead to imprecise predictions. Additionally, hypothesis checking (t-test, F-test) is null due to the uncertainty of the predicted regression coefficients in the covariance matrix (Muhammad, 2012). In this analysis, heteroscedasticity testing was adopted which measures the null hypothesis of homoscedasticity or the absence of heteroscedasticity in linear regression models. The test tested the null hypothesis that all the fitted values of the Cash Holding working models had no heteroscedasticity at the $5 \%$ significance level, as against the alternative. Table 2 . indicates a hottest (Chi2) of 0.01 for all fitted values of Cash Holding. The test was not statistically significant at $\alpha=5 \%(p>0.05)$. The study, therefore, accepted the null hypothesis that there was no heteroscedasticity among the fitted values of Cash Holding. 
Table 3. Test for Heteroscedasticity

\begin{tabular}{lll} 
Model & Chi2(1) & Pro>chi2 \\
\hline Cash_H & 0.01 & 0.9140 \\
\hline
\end{tabular}

\subsubsection{Test for Multicollinearity}

Multi-collinearity is, as Kenton (2018) explains, the occurrence of high inter-correlations among predictor variables. Multi-collinearity results in broader intervals of confidence and less accurate likelihood values leading to distorted or deceptive outcomes (Kock and Lynn, 2012). Multi-collinearity was observed by the Variance Inflation Factor (VIF) or Tolerance Degree (1/VIF) after the Ordinary Least Squares (OLS) regression with Cash Holding as the response variable and Lev, Prof, SZ, INFL_R and INT_R as the explanatory variables. The rule of thumb was that, a variable with a VIF greater than $5(\mathrm{VIF}>5)$ or a degree of tolerance less than $0.2(1 / \mathrm{VIF}<0.2)$ was considered to be highly collinear with other explanatory variables. As depleted in Table 3, the Lev and Cash Holding, Prof, SZ, INFL_R, and INT_R VIFs with their respective degrees of tolerance (1/VIF) indicated that the variables $[\mathrm{VIF}<5 ; 1 / \mathrm{VIF}>0.2]$ were not highly correlated.

Table 4. Test for Multicollinearity

\begin{tabular}{lcc}
\hline Variable & VIF & $\mathbf{1 / V I F}$ \\
\hline INT_R & 1.37 & 0.730464 \\
\hline INFL_R & 1.36 & 0.737062 \\
\hline Prof & 1.05 & 0.948162 \\
\hline Lev & 1.05 & 0.948279 \\
\hline SZ & 1.04 & 0.962580
\end{tabular}

Mean VIF 1.17

\subsection{Model Specification and Estimation}

The model design evaluation involved choosing the correct practical format for the measured sample variables. According to Asterious and Hall (2011), design errors arise where the regressors' practical model option does not correspond with that of the underlying mechanism leading to the misspecification of models. Besides, concerning the adverse effects on the sampling properties of both estimators and experiments, there can be significant implications of sample misspecification in regression analysis. For this study, the researchers conducted a test to choose between the model of random or fixed effects.

From table 4, the Durbin-Wu-Hausman specification test for the Cash Holding model indicates a chi2 of 25.32 which was statistically significant at the $5 \%$ level $[(\mathrm{p}=0.0000)<0.05)]$. The study, therefore, accepted the null hypostasis that, the fixed effects model was preferred over the random-effects model. The study used the Robust fixed effects regression estimator because of the issue of serial correlation that was detected in the study's diagnostic test. 
Table 5. Model Specification Test Results

$\begin{array}{lll}\text { Model Chi2(2) Prob }>\text { Chi2(2) } & \end{array}$

Cash_H $24.32 \quad 0.0000$

\subsection{Descriptive Analysis}

For the indicator of capital, Lev observed mean values were 0.1180 and standard deviations of 0.1600 . This implies, the companies operated with a significant level of the low total debt of $11.80 \%$. This mean figure of the non-financial institutions in Ghana suggests that firms in Ghana are financed more through equity than debt. Cash Holding had a mean of the value of 1.8826 and a standard deviation of 0.9608 . The average means of 1.8826 implies that companies can settle their short-term debt with the available short-term assets at 1.8806 times. Firms can pay off debts at a minimum of 0.187 and maximum at 4.692 .

Table 6. Descriptive Analysis test

\begin{tabular}{lcccc}
\hline Variable & Mean & Std. Dev. & Min & Max \\
\hline Cash_H & 1.8826 & 0.9608 & 0.187 & 4.692 \\
\hline Lev & 0.1180 & 0.1600 & 0.001 & 0.874 \\
\hline Prof & 0.0181 & 0.2126 & -1.397 & 1.181 \\
\hline SZ & 7.4439 & 0.9064 & 4.636 & 9.041 \\
\hline INFL_R & 13.9956 & 2.8801 & 9.840 & 17.450 \\
\hline INT_R & 20.5746 & 3.9759 & 15.025 & 26.125 \\
\hline
\end{tabular}

Again, Prof and SZ of the firms indicated a mean and standard deviation of 0.0181 and 7.4439, 0.2126, and 0.9064 respectively. Finally, inflation and interest rate exhibited a strong mean, standard deviation as external variables to the study. Inflation and interest rate had a mean of 13.9956 and 20.5746 for the study period.

\subsection{Pearson Correlation analysis}

\subsubsection{Correlational analysis between cash holding and its determinates}

The Pearson's Correlation Coefficient data analysis technique was adopted to establish a link between the capital structure and the cash holding of the firms, and from Table 6, there was a statistically significant relationship between Cash holding and Lev at the significant level of $5 \%[\mathrm{r}=-0.1221,(\mathrm{p}=0.0010)<0.005]$. The inverse relation between Lev and Cash holding indicates that a rise in Cash holding has resulted in a reduction in Lev and vice versa. The association between Cash holding and Lev can be justified by the determination coefficient ( $\mathrm{r} 2=$ 0.2442 ), which implies that Cash holding accounted for $24.42 \%$ of the changes in Lev. The unstudied variables accounted for 0.7558 . ( $2=0.7558$ or $75.58 \%)$. 
Table 7. Correlational Analysis

\begin{tabular}{lllllll}
\hline & Cash_H & Lev & Prof & SZ & INFL_R & INT_R \\
\hline Cash_H & 1.0000 & & & & & \\
\hline Lev & $\mathbf{- 0 . 1 2 2 1 *}$ & 1.0000 & & & & \\
\hline Prof & $\mathbf{- 0 . 1 1 2 3 *}$ & $\mathbf{0 . 1 7 1 8 *}$ & 1.0000 & & & \\
\hline SZ & $\mathbf{0 . 2 5 5 0 *}$ & 0.1504 & 0.1342 & 1.0000 & & \\
\hline INFL_R & -0.0066 & 0.0143 & 0.0210 & 0.0489 & 1.0000 & \\
\hline INT_R & 0.0157 & -0.0485 & 0.0861 & 0.0030 & $\mathbf{0 . 5 0 8 4} *$ & 1.0000 \\
\hline
\end{tabular}

Note: * implies significant at 5\%.

Again, Prof and Cash holding had a negative correlation coefficient of -0.1123 and a probability value of 0.0061 at $\alpha 5$ percent. The negative connection between Prof and Cash holding implies that an increase in Prof has led to a decrease in Cash holding and vice versa. The degree of connection that was between Prof and Cash holding can be shown by the coefficient. The coefficient implies $r 2=0.2246$ that $22.46 \%$ of the Prof is accounted for by Cash holding and $22.46 \%$ of the variation in Prof is explained by Cash holding. The non-study variables accounted for $77.54 \%$ (r2=77.54). Further, the relationship between firm size (SZ) and Cash holding was favorable and statistically significant $(\mathrm{r}=0.2550)(\mathrm{p}=0.0016)<0.5]$. The positive relationship between firm size and Cash holding is an indication that an increase in firm size led to a rise in Cash holding and vice versa, and a reduction in firm size led to a reduction in Cash holding and vice versa. The notch of connection that existed between firm size and Cash holding can also be proved by the determination coefficient $(\mathrm{r} 2=0.0650)$, which implies that $6.50 \%$ of differences in Cash holding were accounted for by firm size and $6.50 \%$ of differences in firm size were explained by Cash holding. The unexplained differences [ $93.5 \%$ or $\left.\left(1-r^{2}=0.9350\right)\right]$ may be aligned with other non-study variables. The nexus between Cash holding and INFL $R$ had a negative and insignificant affiliation. With a coefficient of -0.0066 and a p-value of 0.9366 . Lastly, the study established an insignificantly positive relationship between INT_R and Cash holding at 5\% level [ $\mathrm{r}=0.00157,(\mathrm{p}=0.8487)>0.05]$. Figure 0.8487 being the coefficient of correlation between INT_R and Cash holding implies that as INT_R increased, Cash holding also increased in the same direction and vice versa, and as INT_R decreased, Cash holding decreased in the same direction.

\subsubsection{Regression Analysis}

The regression analysis is a series of statistical processes for estimating the relationships between variables. More precisely, regression analysis lets us consider how the dependent variable's normal value differs as us of the independent variables shifts when the other independent variables are constant. To determine the impact of capital structure on the cash holding of the companies, on Lev, Prof, INFL_R, SZ, and INT_R, the sampled firms' Cash holding has been regressed. The findings are shown in Table 7 . The robust fixed effect regression was analyzed to test the nexus of Cash Holding of firms listed on the Ghana Stock Exchange Market. The finding of the results indicated that Cash holding has a negative and significant affiliation with Lev of the article enterprise studied. With a coefficient of -0.0190 and a p-value of 0.085 . This investigation result implies that a unit change in Cash holding will lead to a -0.0190 unit decrease in Lev. On the relationship between Prof and Cash holding, Prof indicated a favorable link with cash holdings (Coef. $(\beta)$ 0.0363, $p=0.030, p<0.05)$. Similarly, firm size $(S Z)$ had a positive and insignificant association with Cash holding (Coef. $(\beta) 0.1830, p=0.892, p>0.05$ ). The positive connection implies that a unit increase in SZ with lead to a unit increase of 0.1830 of Cash holding for the study firms. The inflation rate, however, had a negative and highly significant affiliation with Cash holding $($ Coef. $(\beta)$ $0.0189, p=0.000, p<0.05)$. The coefficient negative figure implies that when the inflation rate increases it will lead to a unit decrease in Cash holding. Finally, the interest rate (INT_R) had a favorable but an insignificant connection with the enterprise's cash holdings. With a coefficient of 0.0006 and a p-value of 0.816 .

The R-squared value of 0.024 depicts that the explanatory variables accounted for $2.4 \%$ of the variances in Cash holding. while the unexplained variances [97.6\% (100-2.4)] were accounted for by other variables that were not part of the study. The F-value of 18.80 with its probability of 0.0021 indicates that the explanatory variables had a combined significant influence on the firms' cash holdings

The fitted model then became;

Cash_H $=00.1892-0.0190 L e v+0.0363$ Prof + 0.1830SZ $-0.0189 I N F L \_R+0.0006 I N T \_R$ 
Table 8. Robust Fixed Effects Regression Analysis on Cash Holdings

\begin{tabular}{lllll}
\hline Variables & Coef. $(\boldsymbol{\beta})$ & Robust Std. Err & z-statistic & Prob(z) \\
\hline Lev & $-0.0190^{*}$ & 0.0117 & -1.72 & 0.005 \\
\hline Prof & $0.0363^{*}$ & 0.0357 & 1.02 & 0.030 \\
\hline SZ & $0.1830^{*}$ & 0.0225 & -0.14 & 0.009 \\
\hline INFL_R & $-0.0189^{*}$ & 0.0028 & -0.66 & 0.000 \\
\hline INT_R & 0.0006 & 0.0041 & 0.23 & 0.816 \\
\hline cons & 0.1892 & 0.1692 & 1.12 & 0.264 \\
\hline R-squared: & & F-Statistic & 18.80 & \\
\hline Within & 0.0131 & Prob (F) & 0.0021 & \\
\hline Between & 0.3580 & $\begin{array}{l}\text { Number } \\
\text { observed }\end{array}$ & of & 150 \\
\end{tabular}

$\begin{array}{lll}\text { Overall } & 0.0204 & \text { Number of groups } 6\end{array}$

Note: * denote at a significant level of $5 \%$.

\subsection{Discussions on the determinates of cash holdings}

Discussions on the study's main results are discussed in this section. The reviews contribute to the analysis of related articles that endorsed and structured the subject in the order of; the nexus between cash holdings and lev, profitability, size of the firm, interest rate, and inflation rate. The hypothesis developed are discussed in part of the article.

From the analysis, cash holdings were found to have negatively affected the leverage ratio of the firms at the $1 \%$ significant level. The greater the financial leverage of the firms, the lower its cash holding, and vice versa. This result is consistent with the hypothesis that has been developed (H1: there is a significant negative affiliation between firm leverage and cash holdings). The finding of this study regression shown an adverse and a significant nexus between Cash holding and Lev. (coefficient -0.0190 and a p-value of 0.005 ). The article investigates support earlier findings. Caldeira and Loncan (2013) examined the nexus between leverage, cash reserves, and firm valuation for a subset of Brazilian publicly registered enterprises using the fixed-effects estimator by panel data regressions. The investigations of this analysis indicated that debt, both short and long-term, is adversely connected to cash reserves, and lower leverage is also correlated with the number of cash holdings. Similarly, Eneh, Okegbe, and Ndubuisi (2019) investigated the cash holdings of agricultural firms registered in Nigeria for the periods 20082017. The OLS regression test indicated that there exists a negative nexus between enterprise cash holdings and leverage. Aftab et al. (2018) studied the determinates of regional cash holdings among the Asia Pacific, Europe, Africa, North America, Middle East, and South America for the period 2007-2016. With a sample of 47 countries, the analysis was conducted through the Panel Generalized Method of Moments. The results of the regression analysis produce a negative and significant affiliation between cash holdings and industry leverage. However, the finding of this study contradicted the findings of Ginglinger and Saddour (2012) and Ahmed et al. (2018) suggested that there exists a positive relationship between cash holding and a leverage ratio of the companies. The negative influence of cash holding on financial leverage could arise when financial leverage was seen as a substitute for cash that can be used by companies to make investments so that the increase in financial leverage would reduce their cash holdings and vice versa. How easily firms access the capital markets dictates how companies invest with sources of funding coming from the debt that will either reduce or increase their cash holding. The company that has strong external funding sources certainly does not need to have large amounts of cash, because the debt could be used as a substitute for the company's cash to finance its operations and projects (Ahmed et al. 2018)

The second hypothesis was developed to find the link that exists between profitability and cash holdings. ( $\boldsymbol{H} 2$. There is a positive association between profitability and cash holdings). The robust fixed effect regression results produced a statistically favorable significant affiliation between cash holding and enterprise profitability. (coefficient 0.0363 and $a \mathbf{p}<\mathbf{0 . 0 5}, \mathbf{0 . 0 3 0}$ ). The research results agree with other researchers on the positive relationship between the constructs. Kamal (2017) explores the determinants of cash reserves for 417 publicly listed entities whose shares were quoted on the Indonesian Stock Exchange between 2010 and 2016. The 
determinants of the cash holdings used in this study come from the concept of trade-off, pecking order, and organization. The findings prove that there is a significant link between profitability and cash holdings. Aftab et al. (2018) conducted a regionally-based study on 47 countries with an observation of 5757 companies for the year 2007-2016. Through the Panel Generalized Method of Moments concept, profitability had a favorable nexus with the cash holdings of the enterprises. In London, Le et al. (2018) researched the factors that influence corporate cash holdings on registered non-financial enterprises for the period 2011 - 2016. The results of the study investigation indicated a positive and significant affiliation between enterprise size and cash holdings. However, there exists an investigation that has shown a negative outcome. Raheman and Nasr (2007) found a substantial negative association between liquid assets and efficiency over the period 1999-2004, using a survey of 94 Pakistani public firms. In comparison, for four years, Lyroudi and Lazaridis (2000) studied the registered firms on the London Stock Exchange. They observed that the period of cash transfer, the current ratios, and the quick ratios negatively influence on the profitability of companies. Better liquidity control of the company is one of the key goals of every sector. Collecting cash from customers on time, however, helps firms pay short-term debts and protects the company from insolvency in technical matters. On the contrary, the lack of adequate cash control would result in cash deficits, and difficulties in the fulfillment of debts that adversely impact the competitiveness of the company (Vijayakumar, 2011).

The third hypothesis was employed to check the influence that firm size may have on the decision to hold cash by managers. H3. There is a negative/positive affiliation between firm size and cash holdings. (coefficient 0.1830 p-value less than 5 percent 0.009). From the regression analysis, corporate cash holding and enterprise size had a positive and a significant affiliation. This article supports earlier studies that concluded on a positive nexus between cash holdings and enterprise size. A study of 47 regional countries by Aftab et al. (2018) indicated that there exists a positive connection between firm size and cash holding. The article concludes that large firms hold less cash as compare to smaller industries. Similarly, Vein, Ozkan, and Ozkan (2004) suggested that an adverse nexus exits with cash holdings should be expected if the firm size is a proxy for information asymmetry which reflects the external financing costs. Al-Najjar and Belghitar (2011) stated in their research that large firms are less likely to store cash reserves. Likewise, it may be argued that big companies have less knowledge asymmetry (as opposed to small firms), and therefore their executives have more leverage in financial strategies and effect would carry more cash for these firms.

The article control for interest rate and inflation rate as the two variables help managers to decide to hold cash or go in for leverage to financial operation or projects. The inflation rate had an adverse influence on cash holdings (coefficient -0.0189 and $\mathrm{p}<0.05,0.000$ ). indicating that when the inflation rate is high enterprises hold less cash due to the cost associated with holding excess cash. On the part of interest rate, the nexus indicated a positive and an insignificant level at 5\% with a coefficient of 0.0006 and a p-value of 0.816 . Azar et al. (2016) analyze results at the company level but using a cash metric that includes marketable shares, as well as a slightly different criterion for regression. They notice a negative correlation with the short-term interest rates and cash holdings. Again, in U.S Stone et al. (2018) examined the nonlinear association between interest rates and cash holdings using a statistical model for thresholds and the U.S. 1970-2014 details on compu-stata. Although they consider an overall negative relationship using a standard linear regression, when interest rates are poor utilizing the threshold model, they discover a favorable relation.

\subsection{Robustness testing 3 Stage Least Square}

To test the robustness of the study variables with the robust fixed effect regression results, the article employed the 3 Stage Least Square regression method. The endogenous variable; Cash holdings was measured by Cash divided by current liabilities. The exogenous variables; Leverage, profitability, firm size, inflation rate, and interest rate remained unchanged. 


\begin{tabular}{|l|l|l|l|l|}
\hline Variables & Coef. $(\beta)$ & Std. Err & z-statistic & Prob(z) \\
\hline Lev & $-0.72108^{*}$ & 0.4475 & -1.61 & 0.010 \\
\hline Prof & -0.5882 & 0.3375 & -1.74 & 0.081 \\
\hline SZ & $0.0112^{*}$ & 0.02992 & 0.38 & 0.007 \\
\hline INFL_R & $-0.0181^{*}$ & 0.0108 & 1.68 & 0.049 \\
\hline INT_R & 0.0115 & 0.0078 & -1.47 & 0.141 \\
\hline Cons & 1.8785 & 0.2871 & 6.54 & 0.000 \\
\hline RMSE & & & & 0.9408 \\
\hline Chi (2) & & & & 5.38 \\
\hline
\end{tabular}

* denote at $5 \%$ significance level.

The finding from the robustness 3 SLS was affiliated with the robust fixed effect regression. However, profitability had an insignificant negative nexus with Cash holdings.

\section{Conclusion and recommendation}

The prime objective of the article was to investigate the determinates of enterprise cash holding. These factors influence the decision to either hold cash or firm go in for debts to finance the operations and investment projects. The article employed the robust fixed effect regression technique to empirically research the registered enterprises on the Ghana Stock Exchange for the period 2012-2018. From the analysis results, Leverage had a statistically significant adverse connection with industry cash holdings. On the part of profitability, the nexus indicated a positive and significant affiliation with the cash holding of the studied enterprises. Similarly, industry size influence on cash holdings had a favorable indication. The article introduces control variables to test the effect on cash holdings. The inflation rate exited a negative and significant association with cash holdings. Finally, the interest rate had a positive but insignificant affiliation against cash holdings of the registered industry on the Ghana Stock Exchange. Having taken into account the various results, the researchers suggest that because cash reserves are a major determinant of the undertakings studied, the sampled companies should function with a degree of cash reserves that would reduce costs and optimize their productivity. To fund daily operations, enterprise that have low collections on debts should hold enough cash to meet short-term liabilities whiles enterprise that have high collection period of debt hold less cash reserves. Yet again, the finding of the article indicated that managers should be careful of the link between cash reserves and profitability. As the variables have a positive affiliation. Holding cash to finance capital spending is low compared with debt. This confirms the reason why Non-financial enterprise in Ghana has a high cash and cash equivalent in their financial reporting. The researchers further suggest that managers should consider the interest rate, as the high interest rate on borrowing will increase leverage and putting the firms into high leverage ratio which may scare potential investors. Similarly, firms should not hold excess cash but can invest in short-term assets that are easy to convert back to cash to finance pressing liabilities. Finally, authorities of the sampled firms should strive to retain some of their net profits (if any) as part of their long-term financing decisions. This would discourage excessive borrowing with its associated costs.

\section{Reference}

Ahmed, Rizwan, et al. "Determinants of Corporate Cash Holdings: An Empirical Study of Chinese Listed Firms." Corporate Ownership and Control, vol. 15, no. 3, 2018, pp. 57-65, doi:10.22495/cocv15i3art5.

Aftab, Ummar, et al. "The Determinants of Cash Holdings around Different Regions of the World." Business \& Economic Review, vol. 10, no. 2, June 2018, pp. 151-82, doi:10.22547/ber/10.2.7. 
Al-Najjar, Basil, and Yacine Belghitar. "Corporate Cash Holdings and Dividend Payments: Evidence from Simultaneous Analysis.” Managerial and Decision Economics, vol. 32, no. 4, Jan. 2011, pp. 231-41, doi:10.1002/mde.1529.

Anon (2018) "Effects of Financial Leverage on Financial Performance of Supermarket in Kenya: A Case Study of Tusky's Supermarkets in Coast Region.” IJARKE Business \& Management Journal, vol. 1, no. 1. doi:10.32898/ibmj.01/1.1 article08.

Asteriou, D., \& Hall, S. G. (2011). Misspecification: Wrong regressors, measurement errors and wrong functional forms. Applied Econometrics (2nd ed.). London: Palgrave MacMillan. pp. 172-197

Azar, J., J.-F. Kagy, and M. Schmalz. 2016. Can Changes in the Cost of Carry Explain the 9 Dynamics of Corporate Cash Holdings? Review of Financial Studies 29:2194-2240.

Caldeira, Jooo, and Tiago Loncan. "Capital Structure, Cash Holdings and Firm Value: A Study of Brazilian Listed Firms.” SSRN Electronic Journal, 2013, doi:10.2139/ssrn.2329346.

Crossman, A. (2018). Understanding purposive sampling: An overview of the method and its applications. Retrieved from https://www.thoughtco.com/purposive-sampling3026727.

Dittmar, Smith, \& Servaes. (2003). International Corporate Governance and Corporate Cash Holdings. Journal of Financial and Quantitative Analysis.

Doan, Thu-Trang Thi. "The Effect of Cash Holdings on Firm Performance: Evidence from Vietnam Listed Firms." Accounting, 2020, pp. 721-26, doi:10.5267/j.ac.2020.6.012.

Eneh, O.M.-R., Okegbe, T.O., Ndubuisi, A.N. (2019). Determinants of Cash Holdings: Evidence from Agricultural Firms Listed 0n Nigeria Stock Exchange, International Journal of Academic Research in Accounting, Finance and Management Sciences 9 (2): 211-223. http://dx.doi.org/10.6007/IJARAFMS/v9-i2/6169 (DOI: 10.6007/IJARAFMS/v9-i2/6169)

Ferreira, \& Vilela. (2004). Why do firms hold cash? Evidence from EMU countries. European Financial Management.

Foley, C.F., Hartzell, J.C., Titman, S. and Twite, G. (2007), "Why do firms hold so much cash? A tax-based explanation", Journal of Financial Economics, Vol. 86 No. 3, pp. 579-607.

Gichaiya, W. M and Ishmail, D. (2014). Evaluation of Financial Distress: A Case Study of UCHUMI Supermarket Ltd. International Journal of Financial Economics, vol. 3, issue 3, 178-183.

Gill, \& Shah. (2012). Determinants of corporate cash holdings: evidence from Canada. International Journal of Economic and Finance, 4(1).

Ginglinger, Edith, and Khaoula Saddour. "Cash Holdings, Corporate Governance and Financial Constraints.” SSRN Electronic Journal, 2012, doi:10.2139/ssrn.2154575.

Harford, J., Li, K. and Zhao, X. (2008), "Corporate boards and the leverage and debt maturity choices", International Journal of Corporate Governance, Vol. 1 No. 1, pp. 3-27.

Hilgen, M.H., 2015. The determinants of cash holdings: Evidence from German listed firms (Master's thesis, University of Twente).

Jensen, M.C. (1986), “Agency costs of free cash flow, corporate finance, and takeovers”, The American Economic Review, Vol. 76 No. 2, pp. 323-329.

Kamal, N (2017). Determinates of cooperate cash holding: Evidence from Indonesia. Erasmus University Rotterdam (Thesis).

Kock, N., \& Lynn, G. S. (2012). Lateral collinearity and misleading results in variance-based SEM: An illustration and recommendations (PDF). Journal of the Association for Information Systems, 13(7), 546-580.

Le, Duc Hoang, et al. "Determinants of Corporate Cash Holding: Evidence from UK Listed Firms." Business and Economic Horizons, vol. 14, no. 3, July 2018, pp. 561-69, doi:10.15208/beh.2018.40.

Lyroudi, K., \& Lazaridis, Y. (2000). The cash conversion cycle and liquidity analysis of the food industry in Greece. Published http://ssrn.com/abstract=236175.

Muhammad, I. (2012). Introduction, reasons, and consequences of heteroscedasticity. Retrieved from $\mathrm{http}$ //itfeature.com/correlation-and-regressionanalysis/introduction-reasonsand- consequences-of heteroscedasticity.

Myers, Stewart C., and Nicholas S. Majluf. "Corporate Financing and Investment Decisions When Firms Have Information That Investors Do Not Have.” Journal of Financial Economics, vol. 13, no. 2, June 1984, pp. 187-221, doi:10.1016/0304-405x(84)90023-0.

Nguyen, M. H., and Le Mihn, T. (2017). The impact of capital structure on cash holdings on firm value. case of firms listed on the Ho chi Minh stock exchange. International Journal of Economics and Financial Issues. 7(1), 24-30

Ozkan, A. and Ozkan, N. (2004), "Corporate cash holdings: an empirical investigation of UK companies", Journal of Banking \& Finance, Vol. 28 No. 9, pp. 2103-2134.

Raheman, A., \& Nasr, M. (2007). Working capital management and profitability case of Pakistani firms. International Review of Business Research Papers, 3(1), 279-300. 
Razali, N., \& Wah, Y. B. (2011). Power comparisons of Shapiro-Wilk, Kolmogorov-Smirnov, Lilliefors and Anderson-Darling tests (PDF). Journal of Statistical Modeling and Analytics, 2(1), 21-33.

Shapiro, S. S., \& Wilk, M. B. (1965). An analysis of variance test for normality (complete samples). Biometrika, 52 (3-4), 591-611. Al-Najjar, Basil, and Yacine Belghitar. "Corporate Cash Holdings and Dividend Payments: Evidence from Simultaneous Analysis.” Managerial and Decision Economics, vol. 32, no. 4, Jan. 2011, pp. 231-41, doi:10.1002/mde.1529.

Soeters, J., Shields, P., \& Rietjens, S. (2014). Handbook of research methods in military studies. New York: Routledge

Stone, A.-L., B. Gup, and J. Lee. 2018. New Insights about the Relationship between Corpo- 14 rate Cash Holdings and Interest Rates. Journal of Economics and Finance 42:33-65.

Uyar, A. and Kuzey, C. (2014), "Determinants of corporate cash holdings: evidence from the emerging market of Turkey”, Applied Economics, Vol. 46 No. 9, pp. 1035-1048.

Vijayakumar, D. (2011). Cash Conversion Cycle and Corporate Profitability-An Empirical Enquiry in Indian Automobile Firms. International Journal of Research in Commerce, IT \& Management.

Zaheer, S., 2017. The effect of excess cash holding on the value of the firm and stock returns. 